\title{
LÍNGUAS EM CONFLITO EM CURSOS DE LICENCIATURA INTERCULTURAL INDÍGENA
}

\section{LANGUAGE CONFLICT IN INTERCULTURAL INDIGENOUS TEACHER TRAINING COLLEGES}

\section{Maria Gorete Neto*}

\section{RESUMO}

A chegada de povos indígenas na universidade tem aumentado nos últimos anos. Ao mesmo tempo em que as culturas, as línguas e os saberes indígenas contribuem para a qualificação da academia, a presença desses povos traz também muitos desafios. Um deles é como lidar com a multiplicidade de línguas indígenas nesse espaço. Para contribuir nesse debate, este artigo faz uma reflexão sobre políticas linguísticas e a promoção de línguas indígenas em contextos de licenciaturas interculturais. Propõe-se que novas teorias, epistemologias e metodologias de ensino das línguas sejam construídas em conjunto com os povos indígenas com o intuito de facultar a promoção das línguas usadas por esses povos.

Palavras-chave: políticas linguísticas; formação de professores indígenas; línguas indígenas.

\section{ABSTRACT}

Indigenous peoples' presence in Brazilian universities has been increasing in the last years. While Indigenous cultures, languages and knowledge have been contributing to academic enrichment, such presence has also posed several challenges to these institutions. One of them has to do with the multitude of Indigenous languages in these environments. In order to contribute to this issue, this paper aims at discussing how language policies can be built in order to promote indigenous languages in a specific university intercultural teacher education program. It is argued that the development of new theories, epistemologies and methodologies in cooperation with indigenous people is needed in order to improve language policies in the academy.

Keywords: language policies; indigenous teacher training colleges; indigenous languages.

\section{INTRODUÇÃO}

Com o intuito de contribuir para o debate acerca da formação de professores indígenas em nível superior, este artigo discute algumas ações envolvendo as línguas faladas no curso de licenciatura em Formação Intercultural para Educadores Indígenas da Universidade Federal de Minas Gerais (doravante FIEI, UFMG) que conformam a política linguística do curso.

\footnotetext{
* Universidade Federal de Minas Gerais (UFMG), Belo Horizonte (MG), Brasil. mariagorete.neto@ gmail.com
} 
O desenvolvimento de políticas públicas que garantam aos povos indígenas entrada e permanência nas instituições de ensino superior ${ }^{1}$ (doravante IES) é relativamente recente no Brasil e foi especialmente impulsionado pela demanda dos professores indígenas por formação em nível superior. A UNEMAT (Universidade Estadual do Mato Grosso) foi uma das primeiras universidades a implementar o $3^{\circ}$ Grau Indígena, destinado à formação de professores indígenas. Ainda em meados de 2000, várias outras universidades implantaram cursos de licenciatura específica para a formação de professores indígenas em nível superior, via edital PROLIND Programa de Apoio à Formação Superior e Licenciaturas Indígenas - lançado pelo MEC (Ministério da Educação).

Desse período em diante, segundo mapeamento realizado pelo Instituto de Inclusão no Ensino Superior e na Pesquisa (2012), há cerca de 67 IES públicas com algum tipo de ação afirmativa para povos indígenas. Esses dados se referem à reserva de vagas, vagas suplementares e cursos específicos para o público indígena, tais como as licenciaturas interculturais. Conforme dados do INEP (2017), o número de estudantes indígenas matriculados no ensino superior é de aproximadamente 49 mil. Desse total apenas 12.348 matrículas são em instituições públicas e as demais em universidades privadas, conforme tabela apresentada a seguir:

Tabela 1: Matrículas em Cursos de Graduação Presenciais e a Distância

\begin{tabular}{|c|c|c|}
\hline Categoria Administrativa & Total & Indígena \\
\hline Brasil & 8.048 .701 & 49.026 \\
\hline Pública & 1.990 .078 & 12.348 \\
\hline Federal & 1.249 .324 & 8.838 \\
\hline Estadual & 623.446 & 3.348 \\
\hline Municipal & 117.308 & 162 \\
\hline Privada & 6.058 .623 & 36.678 \\
\hline
\end{tabular}

Fonte: INEP, 2017.

Os dados reportados por Cajueiro (2008), referentes aos primeiros anos da inserção indígena no ensino superior, indicavam um número aproximado de cinco mil matrículas indígenas naquele período. Comparados aos dados acima, pode se dizer que houve um grande avanço nessa inserção, já que se multiplicou praticamente por dez o número de indígenas nesse nível de ensino. Entretanto, o número de matrículas nas instituições públicas é ainda muito baixo, cerca de três vezes menos

1. Há, no país, instituições de ensino superior públicas (municipal, estadual ou federal), mantidas pelo Poder Público, e instituições privadas de ensino. 
que nas universidades privadas. Há ainda um longo percurso a se percorrer para que as universidades públicas sejam mais inclusivas.

Mesmo a lei $\mathrm{n}^{\mathrm{o}}$. 12.711/2012, conhecida como lei de cotas, que garante a indígenas, negros e pessoas com deficiência a "reserva de $50 \%$ das matrículas por curso e turno nas universidades federais e institutos federais de educação, ciência e tecnologia, a alunos oriundos integralmente do ensino médio público, em cursos regulares ou da educação de jovens e adultos", tem alcance limitado nessa inclusão.

Ainda não se tem um estudo estatístico oficial que informe os efeitos numéricos dessa lei para os povos indígenas ${ }^{2}$, mas sua efetivação esbarra em aspectos que envolvem os direitos coletivos indígenas. Dentre várias críticas à lei, Baniwa (2013) afirma que sua aplicação só surtirá efeito se as comunidades indígenas estiverem à frente do processo, desde a seleção de quem vai para a universidade passando pelo acompanhamento dos estudantes indígenas no intuito de que os mesmos não percam a conexão com suas comunidades de origem. Além disso, o autor alerta para o risco de homogeneização das políticas de diversidade que são muito diferentes para os três segmentos contemplados na lei. Há, por fim, a permanência na universidade que envolve não só a questão financeira, mas também como os indígenas são recebidos nesse espaço. No ambiente universitário, os estudantes indígenas enfrentam desde casos de racismo e preconceito a espaços físicos e condições muito diferentes da aldeia, incluindo a alimentação, com impactos na saúde física e espiritual. Isso revela o quão complexo é o processo de inserção e de permanência e aponta para a necessidade de que as decisões sejam tomadas em conjunto com os povos indígenas interessados.

No mesmo ano da promulgação da lei de cotas, as Diretrizes Curriculares Nacionais para a Educação Indígena (DCNEI; BRASIL, 2012), artigo 20, parágrafo $1^{\circ}$, afirmam ser compromisso do Estado Brasileiro ofertar formação específica aos professores indígenas, em licenciaturas específicas:

Art. 20 Formar indígenas para serem professores e gestores das escolas indígenas deve ser uma das prioridades dos sistemas de ensino e de suas instituições formadoras, visando consolidar a Educação Escolar Indígena como um compromisso público do Estado brasileiro.

$\S 1^{\circ} \mathrm{A}$ formação inicial dos professores indígenas deve ocorrer em cursos específicos de licenciaturas e pedagogias interculturais ou complementarmente, quando for o caso, em outros cursos de licenciatura específica ou, ainda, em cursos de magistério indígena de nível médio na modalidade normal.

2. Conforme dados do SEPPIR, entre 2013 e 2015 a lei de cotas garantiu o acesso de cerca de 150 mil estudantes negros nas universidades. Informação disponível em: http://www.seppir.gov.br/centralde-conteudos/noticias/2016/03-marco/em-3-anos-150-mil-negros-ingressaram-em-universidadespor-meio-de-cotas Acesso em: 02 abr. 18. 
O parágrafo $5^{\circ}$, da mesma resolução aponta que:

$\S 5^{\circ}$ Os sistemas de ensino e suas instituições formadoras devem garantir os meios do acesso, permanência e conclusão exitosa, por meio da elaboração de planos estratégicos diferenciados, para que os professores indígenas tenham uma formação com qualidade sociocultural, em regime de colaboração com outros órgãos de ensino.

Logo, é necessário que se cumpra minimamente o constante na lei, garantindo tanto o acesso quanto a permanência de indígenas nas universidades públicas, não só se restringindo à formação docente, mas ampliando o acesso para cursos técnicos e de bacharelado (Medicina, Engenharia, Direito, Odontologia, Agronomia, dentre outros) também almejados pelos povos indígenas.

Na UFMG, iniciou-se em 2006 o curso FIEI através do edital PROLIND, que formou, em 2011, 150 professores de sete povos indígenas de Minas Gerais: Xakriabá, Maxakali, Krenak, Pataxó, Kaxixó, Xukuru-Kariri e Pankararu. Em 2009, esse curso de licenciatura, foco de reflexão nesse artigo, foi oficializado. O curso possui quatro habilitações: Ciências Sociais e Humanidades (CSH), Matemática (MAT), Ciências da Vida e da Natureza (CVN), Línguas, Artes e Literatura (LAL). O processo seletivo é específico e ocorre anualmente para preencher 35 vagas.

O FIEI funciona em formato de alternância, com Etapa Intensiva (módulo) na universidade e Etapa Intermediária (intermódulo) nos territórios indígenas, a cada semestre. No âmbito administrativo, o curso conta com um colegiado formado por discentes indígenas e docentes e ainda com o Conselho Consultivo Indígena composto de 14 lideranças com representantes de todas as etnias do curso. O financiamento é feito através de recursos do MEC. Em 2018 colou grau a sexta turma do curso, o que perfaz um total aproximado de 210 indígenas formados.

Ainda em relação ao acesso dos povos indígenas na UFMG, um projeto piloto de vagas suplementares facultou, no período de 2010 a 2013, o ingresso de 46 indígenas nos cursos de Enfermagem, Medicina, Ciências Biológicas, Ciências Sociais, Agronomia e Odontologia por meio de processo seletivo específico. Em 2016, a UFMG instituiu, em caráter permanente, o Programa de Vagas Suplementares através da Resolução No 15/2016, de 30/08/16.

Sobre o acesso à Pós-Graduação, foi aprovada a Resolução n ${ }^{0}$ 02/2017, de 04 de abril de 2017, que dispõe sobre a Política de Ações Afirmativas para inclusão de pessoas negras, indígenas e com deficiência na Pós-Graduação stricto sensu na Universidade Federal de Minas Gerais. Em seu artigo $6^{\circ}$ é afirmado que 
Art. $6^{\circ}$ Para o acesso de candidatos indígenas, serão publicados, anualmente, editais específicos com a oferta de, no mínimo, uma vaga suplementar em cada curso de Mestrado Acadêmico, Mestrado Profissional e Doutorado da UFMG.

Essas duas últimas resoluções estão em fase de implementação, justamente para atender aos aspectos apontados por Baniwa (2013), mencionados anteriormente.

A entrada desses povos na universidade traz importantes mudanças no fazer acadêmico, ensejadas pelo questionamento que as diferentes culturas, línguas, cosmovisões indígenas fazem às consolidadas estruturas da academia:

Ao incluir os indígenas nas universidades há que se repensar as carreiras universitárias, as disciplinas, abrir novas (e inovadoras) áreas de pesquisa, selecionar e repensar os conteúdos curriculares que têm sido ministrados e testar o quanto estruturas, que acabaram se tornando tão burocratizadas e centralizadoras, podem suportar se colocar ao serviço de coletividades vivas histórica e culturalmente diferenciadas. (LIMA e BARROSO-HOFFMANN, 2004, p. 19)

Esse repensar a universidade tem sido uma tarefa complexa. Conforme dizem os autores acima, há muitos entraves burocráticos na implementação das resoluções. Há também conceitos, saberes e epistemologias muito cristalizados, nem sempre de fácil demoção. Além disso, a premência das demandas obriga as equipes que lidam com os povos indígenas a construir o fazer e o aprender ao mesmo tempo. Essa contingência leva a ações exitosas e a outras nem tanto.

Um dos inúmeros desafios tem sido lidar com as diferentes línguas indígenas que adentram a universidade, incluídas aqui as línguas vernáculas faladas pelos povos indígenas que normalmente são chamadas de variedades de português-indígena. Essa reflexão adquire importância ao se considerar o silenciamento histórico das línguas indígenas e o papel da língua(gem) na construção das identidades (HALL, 1992; MAHER, 1996). Hall (1992) afirma que a língua(gem), enquanto discurso, tem papel essencial na construção de identidades. As identidades - o representarse a si em contraste ao outro (SILVA, 2000) - são múltiplas, instáveis, construídas na e através da língua, na interação com outros atores e são histórica e socialmente contextualizadas. As identidades não estão associadas a uma língua somente, elas são construídas por meio de qualquer língua, conforme indica Maher (1996) ao abordar a temática da construção de identidades indígenas.

Considerando essa relação entre língua(gem) e identidades, este artigo, como já dito, busca refletir sobre as ações que envolvem as línguas faladas no FIEI no intuito de contribuir para a construção de políticas linguísticas com vistas à promoção das línguas faladas pelos estudantes indígenas. 


\section{ALGUNS SIGNIFICADOS DO CONCEITO 'LÍNGUA' E SUAS IMPLICAÇÕES PARA O CONTEXTO INDÍGENA}

Nesse artigo, assumo o pressuposto de que língua é um construto fluido, histórica e socialmente construído na interação entre os falantes. A língua, enquanto discurso, representa, cria e constrói continuamente identidades, conforme referido. Entretanto, como vários pesquisadores vêm questionando (CAVALCANTI e MAHER, 2017; CÉSAR e CAVALCANTI, 2007; SHOHAMY, 2006) o termo língua é impreciso do ponto de vista científico, polissêmico, pautado pelo eurocentrismo.

Há mais de um século, Saussure definiu língua como um sistema estruturado de signos (SAUSSURE, 1970). O autor estabeleceu a distinção entre 'língua' e 'fala': 'língua', sistema formal, abstrato, de valores imutáveis, homogêneos, depositado como produto social na mente dos indivíduos, passível de ser objeto de análise pela Linguística, e 'fala', ato individual, dependente de fatores externos, variável e, portanto, inadequado à ciência Linguística:

\footnotetext{
Nossa definição de língua supõe que eliminemos dela tudo o que lhe seja estranho ao organismo, ao seu sistema, numa palavra: tudo quanto se designa pelo termo "Linguística externa". [...] No que concerne à Linguística interna, as coisas se passam de modo diferente: ela não admite uma disposição qualquer; a língua é um sistema que conhece somente sua ordem própria. (SAUSSURE, 1970, p. 29; 31)
}

Por outro lado, Chomsky, em seus estudos gerativistas (1978; 1998), afirma que língua é um sistema de princípios radicados na mente humana. Para o autor todas as línguas têm um sistema comum, que ele denominou de Gramática Universal, e é dessa gramática interna, mental que a Linguística deve se ocupar. O autor cunhou os termos 'competência' - conhecimento tácito do sistema da língua -, e 'performance' - o uso do idioma em situações concretas. Tanto a concepção estruturalista de Saussure quanto a noção mentalista de Chomsky suprimem do conceito 'língua' seu contexto de uso por considerarem que isso tira a cientificidade do objeto 'língua' para o estudo da Linguística.

Bakhtin (1997; 1979), por sua vez, questiona as acepções acima e afirma que a língua é heterogênea, sempre afetada pelo que lhe é externo, sendo este exterior constitutivo da língua. A língua, enquanto discurso, ou linguagem, é historicamente situada na comunicação concreta e não no sistema abstrato das formas da língua. A língua não é neutra, é dialógica, está associada a relações de poder, emerge da interação entre os falantes e está atrelada a outros discursos.

No contexto brasileiro, César e Cavalcanti (2007) problematizam o conceito língua, afirmando que suas implicações ideológicas a serviço da colonialidade 
têm garantido uma durabilidade ao termo não só no campo científico quanto no imaginário social e funciona muito bem para se fazer "esquecer" do seu caráter de construção teórica, sociohistoricamente implicada. As autoras afirmam que esse imaginário da língua termina reverberando e prejudicando o trabalho com os povos indígenas e outras minorias linguísticas, por configurar-se como algo dado, pouco afeito a questionamento, de modo que a multiplicidade e complexidade de usos (meta) linguísticos têm que ser constrangidas a caber na 'língua', um construto teórico, ou pelo menos um termo corrente, neutralizador das diferenças. Para ilustrar essa inadequação, César e Cavalcanti (2007) citam o caso de alguns povos indígenas nordestinos que, segundo estudos linguísticos e antropológicos sustentados em aportes estruturalistas, não falariam mais sua língua. Essa afirmativa tem desagradado a esses povos que constantemente rebatem essas ideias ao mesmo tempo em que se empenham em agir criativamente em relação a suas línguas ancestrais.

Os pesquisadores, de uma forma geral, ao assumirem a concepção essencialista de língua parecem não se atentar para as implicações que esse uso pode ter para povos indígenas. Dizer que um povo indígena não fala mais sua língua ou dizer que o que se tem não é língua tem implicações tanto para a autoestima do povo quanto para a garantia de seus direitos, como observa o pesquisador e professor Pataxó Uilding Braz:

[...] na visão de muitos linguistas a língua Pataxó não seria considerada como língua Pataxó uma vez que usa elementos morfossintáticos da língua portuguesa. Felizmente, nós, apesar de sermos alvos de críticas e de contradições por muitos dos/das linguistas, insistimos em querer algo nosso não apenas por causa do outro como dizem, mas por motivo de termos o compromisso e respeito com nós mesmos, com nossos ancestrais, anciãos e com nosso povo, não é o caso de pensar em uma língua "pura" visto que a língua está em constante relação com outras, ocorrendo assim o empréstimo linguístico e com relação à língua Pataxó o empréstimo é valorizado. (BRAZ, 2016, p. 37)

Ao criticar os linguistas e sua concepção inoperante de língua para o contexto Pataxó, Braz (2016) torna visível a violência pela qual muitos povos indígenas passaram e passam, reproduzida e mantida inadvertidamente pela academia. Inúmeros povos indígenas foram obrigados a silenciarem sua língua por força da violência do contato, embora a memória desse repertório linguístico permaneça nas aldeias. Quando os estudiosos, a partir de conceitos enrijecidos, afirmam que as línguas adormecidas são consideradas línguas extintas, reafirmam e impõem a continuidade do silenciamento sofrido.

As consequências desse posicionamento acadêmico corroboram e reforçam o posicionamento de setores anti-indígenas que reiteradamente usam o argumento "se fala português não é índio, portanto, não tem direito à terra" - para desqualificar 
a luta indígena por seus territórios imemoriais e por outros direitos. Buscando contribuir para a luta política desses povos (e de outras minorias linguísticas), César e Cavalcanti (2007) propõem a noção caleidoscópica de língua:

O caleidoscópio, sendo feito por diversos pedaços, cores, formas e combinações, é um jogo de (im)possibilidades fortuitas e, ao mesmo tempo, acondicionadas pelo contexto e pelos elementos, um jogo que se explica sempre fugazmente no exato momento em que o objeto é colocado na mira do olho e a mão o movimenta; depois, um instante depois, já é outra coisa. No caleidoscópio formam-se desenhos complexos a partir de movimentos, de combinações. Parece uma imagem feliz para descolar as concepções de língua das concepções de nação e território estabilizadas politicamente e de níveis hierárquicos, num caso e num outro, totalidades que se mantêm como "grande narrativa", justamente por conta de um arcabouço teórico anacrônico. (CÉSAR e CAVALCANTI, 2007, p. 61)

As imagens forjadas pelo caleidoscópio nunca são as mesmas, o que se aplica à língua se se considera sua plasticidade e historicidade. Também Braz (2016) propõe um novo conceito de língua, apontando para a necessidade de que ele seja compreendido de maneira situada, ao utilizar a metáfora de uma árvore que foi podada e rebrota, mas guardando suas raízes ancestrais:

Desta forma, assim como nossos avós têm experiência multiplicada, a árvore nova poderia até estar fina, mas ela teria sua base forte, e é dessa forma que imaginamos a nossa língua. Uma língua que não é isolada, uma língua cortada, onde fomos obrigados a não falar e por consequência disso até fomos chamados de povo sem língua. Mas, hoje podemos dizer que nossa língua está emergindo dos nossos anciãos. E como a árvore nova não é a mesma árvore velha, a nossa língua também não é e nem seria. (BRAZ, 2016, p. 38)

Tanto a acepção de língua como caleidoscópio como de árvore que rebrota admitem as múltiplas e complexas facetas da realidade sociolinguística na qual está inserida boa parte dos povos indígenas brasileiros. Do ponto de vista caleidoscópico, a língua passa a ser um conjunto indefinido de combinações. Sob o ponto de vista de língua como árvore que rebrota, visibiliza-se a capacidade de resistência e resiliência indígena. A língua está nas raízes, na memória do povo que age criativamente para fazê-la rebrotar. Torna-se possível compreender e considerar os processos históricos pelos quais passam as línguas, permitindo a valorização e promoção do que se tem de língua hoje e não no passado remoto. Permite, principalmente, compreender os usos que os falantes fazem dessas línguas, usos estes que não cabem nos binarismos tais como "isso é língua, isso não é".

Da discussão acima depreende-se que uma acepção essencialista de língua não favorece a construção de políticas linguísticas que promovam as línguas indígenas na universidade, uma vez que não permite a compreensão mais ampla dos múltiplos recursos linguísticos que ocorrem nesses espaços multiculturais e multilíngues. 


\section{POLÍTICAS LINGUÍSTICAS E O PAPEL DA UNIVERSIDADE}

Assim como o conceito língua, a definição de política linguística tem sido fartamente debatida. Calvet (2002, p. 145) define "política linguística como um conjunto de escolhas conscientes referentes às relações entre língua(s) e vida social, e planejamento linguístico como a implementação prática de uma política linguística, em suma, a passagem ao ato". A política linguística seria o mecanismo primário de controle do comportamento linguístico e consiste em decisões sobre as línguas e seus usos em sociedade. São essas decisões que conferem prestígio a determinada língua em detrimento de outra, que definem qual língua deve ou não ser falada/ensinada (onde, como, quando e em que contextos). As políticas linguísticas estão manifestas, sobretudo, em documentos específicos, leis, regulamentos que determinam o comportamento linguístico de determinado povo. Nesse caso, primeiro, formula-se uma política linguística com objetivos bem delimitados e, posteriormente, planejam-se e implementam-se as ações com o intuito de atender aos objetivos propostos. Ainda que diferentes atores possam construir políticas linguísticas, segundo Calvet (2002), apenas o Estado tem força e poder de impor determinadas escolhas linguísticas.

Spolky (2004) afirma, por sua vez, que para entender o que é política linguística é necessário atentar-se mais às práticas e representações linguísticas de determinada comunidade do que necessariamente limitar-se ao que diz a legislação oficial. Isso porque, conforme o autor, nem sempre a política linguística oficial teria efeito nas práticas linguísticas locais. Spolky, citado anteriormente, explica que há políticas linguísticas explícitas (legislação oficial, por exemplo) e outras que estão implícitas (em materiais didáticos, nos usos que as pessoas fazem das línguas no dia-a-dia, em exames, etc). Para o autor, as políticas implícitas são mais efetivas que as explícitas, pois elas é que demonstram os valores das línguas em uso em determinado contexto.

Shohamy (2006, p. 58), partindo das reflexões de Spolky, propõe uma compreensão ampla de política linguística. A autora aponta não haver uma distinção entre política e planejamento linguístico. Para Shohamy (2006, p. 130), as ideologias ou representações linguísticas estão associadas ao pressuposto de um estado-uma nação que, por sua vez, associam-se à ideia de uma língua-uma nação, ou seja, língua como marcador de uma identidade nacional. As ideologias fomentam e estão interligadas a quatro grandes mecanismos de políticas linguísticas tais como leis, regulamentos e regras; educação linguística; testes linguísticos; linguagem em espaços públicos; ideologias, mitos, propagandas e coerção que culminam na política linguística de fato, ou seja, que terminam por afetar as práticas linguísticas 
efetivas. Observe-se que como a língua não é neutra, mas permeada por agendas econômicas, políticas, ideológicas e sociais, os referidos mecanismos também não são neutros. Ao contrário, são veículos de perpetuação e promoção dessas agendas. Há, assim, um constante embate entre as representações linguísticas (ou ideologias) e as práticas linguísticas efetivas. Esse embate se dá em arenas de poder que culminam nos movimentos de resistência linguística.

No contexto brasileiro, por exemplo, a partir da era pombalina no final do século XVIII, a língua portuguesa foi imposta como língua oficial. O decreto visava consolidar o pressuposto de 'um estado, uma nação, uma língua', por um lado, e por outro, sufocar as línguas faladas no território brasileiro, principalmente o Nheengatu, que funcionava como língua franca em toda a costa brasileira nas interações entre indígenas e não indígenas (CAVALCANTI e MAHER, 2018). Os efeitos dessa política para as línguas indígenas foram desastrosos, culminando com o desaparecimento de muitas delas. Ainda hoje é corrente no país o mito do monolinguismo em Português (CAVALCANTI, 1999) que invisibiliza as cerca de 274 línguas indígenas remanescentes (IBGE, 2010).

Mesmo com avanços no texto da lei como, por exemplo, a Constituição Federal de 1988, que garante o uso das línguas indígenas, o decreto 5.626 de 23.12.2005, que torna Libras (Língua Brasileira de Sinais) a língua oficial dos surdos e a cooficialização de nove línguas ${ }^{3}$, falta muito ainda para que o país se reconheça multilíngue $e^{4}$. Um desses termômetros é a educação escolar. Conforme assinalam Cavalcanti e Maher (2017), no plano educacional não se leva muito em consideração a diversidade linguística, embora nos Parâmetros Curriculares Nacionais ( $\mathrm{PCN}_{\text {; }}$ BRASIL, 1997) haja menção à diversidade cultural.

Nesse sentido, a consolidação de programas de formação superior para os povos indígenas converte-se em uma possibilidade de fortalecimento, reconhecimento e promoção dessas línguas o que poderá contribuir para um melhor conhecimento desses povos, suas línguas e culturas pela sociedade não indígena. Em especial, no que se refere a línguas indígenas, a presença desses povos na universidade nos força a pensar em políticas linguísticas que, por um lado, rompam com o monolinguismo imposto em língua portuguesa, visibilizando as apropriações

3. São cooficializadas no Brasil 9 línguas, em 12 municípios. Destas línguas, 5 são indígenas - Nheengatu, Baniwa, Tukano em São Gabriel da Cachoeira (AM); Guarani em Tacuru (MS); Akwê Xerente em Tocantínia (TO) - e 4 são línguas de migração: Pomerano, em Santa Maria de Jetibá, Domingos Martins, Pancas, Laranja da Terra Vila Pavão (ES) e Canguçu (RS); Talian, em Serafina Côrrea (RS); Hunsrükisch, em Antônio Carlos (SC) e Alemão, em Pomerode (SC) (cf. MORELLO, 2012, p. 9).

4. Além do Português, das línguas indígenas e da Libras, no Brasil são faladas línguas de imigrantes (Japonês, Italiano, Alemão, dentre outras), línguas de matriz africana, língua de sinais do povo indígena Urubu-Kaapor, e também inúmeras variedades de português (cf. CAVALCANTI, 1999). 
que os diferentes povos fazem desse português imposto, seja como primeira ou segunda língua, e que, por outro, promovam as línguas ancestrais.

\section{A CONSTRUÇÃO DE POLÍTICAS LINGUÍSTICAS NO FIEI}

No FIEI $^{5}$ há a presença das etnias: Maxakali (MG), falante da língua Maxakali; Guarani (ES, RJ, RS) falante da língua Guarani; Xakriabá (MG), Pataxó (MG e BA), Pataxó Hã Hã Hãe (BA), Tupiniquim (ES), falantes de Português. Em termos percentuais, cerca de $85 \%$ falam português como primeira língua e apenas $15 \%$ falam Guarani e Maxakali. Esses dois grandes grupos têm demandas muito distintas em relação à temática 'língua'. O primeiro busca conhecimentos para a realização de projetos de reavivamento ${ }^{6}$ de suas línguas adormecidas e aperfeiçoamento do português padrão enquanto que o segundo grupo procura fortalecer suas línguas primeiras e aprimorar o português como segunda língua. É comum a todas as etnias a obrigatoriedade de aprender o português acadêmico que, via de regra, conflita-se com a diversidade dos vernáculos por eles falados, chamados, de forma naturalizada, de variedades do português ou do português-indígena.

A versão em vigor do Projeto Político Pedagógico do FIEI (2009), na seção Objetivo e Perfil do Egresso, informa que o estudante indígena será formado para atuar prioritariamente nas escolas indígenas de suas comunidades e responder às necessidades de seu povo. Nos Princípios Norteadores ${ }^{7}$ do curso, não há menção explícita ao papel desse docente no que diz respeito às línguas indígenas, exceto ao fato de as escolas indígenas serem bilíngues:

Dessa forma, o curso tem como princípios: A contextualização do processo de formação, tendo como referência a realidade dos povos indígenas, em especial a realidade da educação escolar indígena no país, tanto no que se refere às políticas públicas vigentes como aos diversos processos de implantação das escolas indígenas específicas, interculturais e bilíngues. (FIEI, 2009, p. 17)

Prevê-se a formação do professor considerando a natureza 'específica, intercultural e bilíngue' das escolas indígenas, mas de uma maneira genérica. $\mathrm{O}$ currículo FIEI estrutura-se da seguinte forma:

5. Como parte do corpo docente do FIEI, estou implicada nas reflexões aqui apresentadas.

6. O uso da palavra 'reavivamento' deve-se ao fato de que os povos indígenas do curso se referem dessa forma às suas línguas em processo de revitalização.

7. Os princípios norteadores do curso são: (i) a contextualização do processo de formação; (ii) o destaque na relação com o território; (iii) o vínculo com projetos sociais das comunidades indígenas; (iv) o acolhimento e o tratamento da diversidade; (v) o diálogo intercultural e (v) o ensino pela pesquisa. 
O eixo curricular do curso se centrará no tema integrador: ser educador intercultural indígena, desenvolvido através do eixo: A Escola Indígena e Seus Sujeitos, envolvendo as áreas de educação intercultural, educação escolar indígena e formação de professores. Os eixos específicos estão voltados para a formação do educador intercultural em cada área de conhecimento, em seus aspectos teórico-conceitual-metodológicos: o conhecimento socioambiental, envolvendo as áreas de Ciências da Vida e da Natureza e Ciências Sociais e Humanidades; as múltiplas linguagens, envolvendo as áreas de Línguas, Artes e Literatura e Matemática. (FIEI, 2009, p. 18)

Essa estruturação significa que há um conjunto de disciplinas obrigatórias a todos os estudantes, referentes ao eixo integrador Escola e Seus Sujeitos, e que as demais estão alocadas nas habilitações. Nesse rol de disciplinas obrigatórias há apenas uma disciplina que aborda questões de uso da linguagem nomeada "Leitura e produção de textos acadêmicos". Ainda assim, não se trata de promoção de línguas indígenas, mas sim de aprendizagem do português acadêmico exigido pela universidade. Além dessa disciplina, há o Seminário Temático denominado 'Políticas Linguísticas' que pode ou não ser ofertado, a depender das negociações internas do curso. Isso significa que a discussão sobre as línguas indígenas do/no curso fica no plano individual, caso algum professor se sinta habilitado a discutir essas questões nos programas de disciplinas com ementas mais flexíveis como 'Estudos Orientados', quando possível. No currículo, dessa forma, há um reconhecimento da importância das línguas indígenas de forma ampla, mas não se concretiza, em termos de proposta curricular, a formação dos docentes indígenas para lidar com suas línguas. Por lidar com suas línguas entende-se o refletir sobre suas línguas, serem capazes de fazer propostas no sentido de promovê-las e ajudar suas comunidades a debater o tema. Isso não é incumbência somente dos que fazem habilitação em Línguas, Artes e Literatura uma vez que sabidamente os professores indígenas cumprem um papel muito amplo nos seus territórios, que escapam à formação em habilitações específicas.

Embora haja essas lacunas em termos de distribuição de disciplinas na proposta curricular ${ }^{8}$, pode-se dizer que há um esforço por parte do FIEI em criar espaços de circulação para essas línguas, aproveitando que o currículo é, de certo modo, flexível. Um deles é o Seminário Temático, evento semestral que aborda questões variadas de interesse amplo dos povos indígenas. Realizado todo módulo, esse seminário busca quebrar a hierarquia entre saberes tradicionais e saberes acadêmicos e, para isso, as mesas sempre são compostas por sábios indígenas das distintas etnias contempladas no curso, bem como de representantes de outros

8. Cumpre reforçar: disciplinas que sejam obrigatórias para todos os estudantes indígenas, independente da habilitação. 
povos indígenas. É um momento em que o português-indígena e as demais línguas são ouvidas e veiculadas no espaço prestigioso da universidade.

Essa ação poderia ser potencializada se houvesse intérpretes para que o direito dos sábios indígenas a se comunicar em sua primeira língua fosse possível e para que efetivamente línguas como o Guarani e o Maxakali possam ser utilizadas/ouvidas em espaços públicos, em grandes audiências. Além disso, as línguas indígenas do FIEI são veiculadas nos rituais públicos organizados pelos estudantes indígenas. Nesses rituais são entoados cânticos em Guarani, Maxakali, Akwen (Xakriabá), Patxôhã (Pataxó) e em português-indígena.

É preciso que falantes de línguas minoritárias vejam suas línguas sendo utilizadas em espaços de prestígio, normalmente ocupados pelas línguas majoritárias (escolas, universidades, materiais didáticos, livros, dicionários, dentre outros) (cf. D’ANGELIS, 2005). Esses espaços, aqui também incluídos os currículos, conforme Shohamy (2006), são alvos preferenciais de políticas linguísticas dominantes, em função do poder da escolarização na consolidação de certas escolhas linguísticas. Não se tem a ilusão de que isso vá "salvar ou preservar línguas". Interessa aqui o status que é dado a uma língua indígena que fora excluída desses espaços por serem consideradas menores e o papel que essa ação tem na autoestima dos falantes.

É ainda nas brechas do currículo que algumas outras ações têm se dado. Um desafio que tem sido posto ao FIEI é ensinar o português acadêmico sem silenciar as variedades indígenas do português. Algumas estratégias podem ser relatadas. Em disciplinas como 'Produção e leitura de textos acadêmicos' e 'Estudos Orientados', a depender do professor que as ministra, os estudantes aprendem as técnicas de elaboração de textos acadêmicos orais e escritos. Nessas disciplinas são também debatidos conceitos, tais como, o de língua e seus impactos para os povos indígenas, as diferenças entre o português indígena e o português acadêmico bem como as implicações do uso de uma ou outra variedade. Para além disso, os professores do curso têm buscado valorizar os textos escritos em português indígena e têm incentivado a manifestação de gêneros específicos do português indígena como, por exemplo, as 'loas' do povo Xakriabá. Lopes (2016, p. 15) explica que as 'loas' são versos, normalmente utilizados nos casamentos Xakriabá. Entretanto, muitos estudantes dessa etnia vêm utilizando esse recurso para fazer seus resumos e relatórios acadêmicos.

Há, no entanto, muitas dúvidas por parte da equipe FIEI, boa parte dela não especialista em Estudos da Linguagem, sobre o que é o português indígena. Os estudos sobre essa temática só têm sido divulgados muito recentemente e necessitam de ampliação e aprofundamento (cf. MAHER, 1996; GORETE NETO, 
2005; LIMA e SILVA, 2011). Não raro o português indígena é confundido com falar português gramaticalmente incorreto (não fazer concordância nominal ou verbal tal como prescrita nas gramáticas normativas, cometer equívocos ortográficos, etc). Porém, não é disso que se trata o português indígena. Essa variedade de português traz a memória das línguas ancestrais orais, seja na estrutura, seja no vocabulário, seja na organização do discurso. Um texto escrito em português indígena pode apresentar recursividade, retomada do discurso conforme é realizado no texto oral indígena, pode espelhar a estrutura da língua originária sem prejuízo ao entendimento do texto em português, pode trazer vocábulos especificamente utilizados pelo povo no seu território, dentre outras características. Nos trechos abaixo, retirados de percursos acadêmicos ${ }^{9}$ de estudantes indígenas do FIEI, é possível verificar a ocorrência do português indígena. O trecho 1 e de uma formanda Xakriabá:

\section{TRECHO 1}

Todos da mesa são servidos de todos os tipos de comidas, bebidas e doces. Quando todos terminam de comer e beber, então é hora das Loas. Aqui a gente não diz falar loa, se diz jogar loa. Quem joga loa normalmente senta na cabeceira da mesa, a Loa é jogada com um copo de cachaça arribado. Depois de falar a Loa, bebe-se a cachaça. (LOPES, 2016, p. 22-23)

No trecho acima observa-se obediência à norma padrão da língua, mas uma proximidade com o português oral, falado pelo povo Xakriabá, como, por exemplo, em "então é hora das Loas", "aqui a gente não diz falar loa, se diz jogar loa" e ainda no uso do vocabulo "arribado" (levantado, suspenso) de uso corrente pelos falantes no território desse povo.

O trecho 2, na sequência, é de um formando Guarani. Nesse caso, será observado que as frases estão em uma ordem não convencional no português padrão:

\section{TRECHO 2}

Guarani vive alguns é só no artesanato, faz varias as peças da cestinha grande, pequeno, médio. As cestinhas têm três. É assim que nós guarani trabalha de artesanato. (SOUZA, p. 33; 35)

Se houvesse uma tradução do trecho para o português padrão, uma construção possível seria a seguinte: "Alguns Guarani vivem só de artesanato. Eles fazem várias peças de cestinha: grande, pequena e média. Têm três cestinhas. É assim que nós, Guarani, trabalhamos com artesanato.". Estudos sobre a língua Guarani (Dooley,

9. Os percursos acadêmicos são pesquisas realizadas pelos estudantes indígenas ao longo do curso, sob a orientação de um docente, cujo tema deve estar relacionado às demandas de suas comunidades. O resultado dessas pesquisas pode se materializar em monografias, vídeos, catálogos, materiais didáticos, dentre outros. A defesa e entrega da versão final do percurso acadêmico é condição para que o estudante cole grau. 
1998) indicam que embora a ordem básica dos constituintes nessa língua seja sujeito, verbo, objeto, há muita variação na referida ordem em função de fatores discursivos. Talvez possa ser dito que esse fenômeno que ocorre em Guarani é o também presenciado no português guarani retratado acima.

Na sequência, no trecho 3, um pouco mais longo, é possível observar nos dois primeiros parágrafos que o autor segue a estrutura de um artigo acadêmico, inclusive com citação de outra obra, e, ao final, mesmo ainda seguindo essa estrutura, aproxima-se mais do português falado por sua comunidade:

\section{TRECHO 3}

Referente a alguns comportamentos dos Pataxó, o príncipe Maximiliano Wied Neuwied, viajante austríaco que caminhava pela região entre 1816 a 1817, relata vários episódios de contato entre Pataxó e não indígenas, episódios estes que nem sempre eram de amizade, pois enquanto o príncipe estava na região descreveu alguns acontecimentos. Dentre eles, descreveu um ataque contra os moradores da vila do Prado, a troca de cera de abelha por comida ou tecido e a venda de uma índia possivelmente do Povo Botokudo:

[...] tanto os Patachós como os Machacaris vivem nas florestas da região, às margens do Jucuruçu. Os últimos sempre se mostraram mais inclinados à paz com os brancos do que os primeiros, que somente chegaram a um acordo amigável havia três anos. Pouco ano disso, porém, surpreenderam na floresta alguns habitantes do Prado, ferindo o escrivão e matando várias pessoas. Os Machacaris amigos foram depois chamados como medianeiros da paz com os Patachós.[...] Parece que ambos os povos se aliaram com os Botocudos, e que tratam os prisioneiros como escravos, pois, no Prado, uma menina botocuda foi, há pouco tempo, oferecida à venda. [...] Vagueiam pelas matas, e suas hordas surgem, alternadamente, no Alcobaça, no Prado, em Comechatiba, Trancoso, etc. Chegando a qualquer lugar, os moradores lhes dão algo para comer, trocando com eles miudezas com cera e outros produtos da mata, após o voltam as brenhas. (WIED, 1840, citado por CRUZ, 2015, p. 14-15).

Então era desta forma que vivíamos antes da chegada dos ĩdxihi em nossas terras. Com muita liberdade para andar e viver pelas grandes matas e pelo território que nossos Niamisũ deixaram para nós. Cuidamos muito bem de nossa mata e de nossas terras até que chegou o homem da outra esfera criadora e foi destruindo tudo. Enquanto vivíamos livres pelas grandes matas os ĩdxihi planejavam nosso extermínio. (BRAZ, p. 15-16)

O trecho inicia-se com "Referente a alguns comportamentos dos Pataxó". A construção 'referente a...." ao invés de "No que se refere a", aproxima-se mais do português Pataxó oral. Além do uso do vocábulo 'então', normalmente utilizado em início de frases em contextos mais informais, há a presença de palavras da língua Patxôhã, 'Niamisũ' (deuses), 'ĩdxihi' (não indígena). Há ainda o uso de 'nosso, nossos', maneira muito própria do discurso de povos indígenas para se referirem coletivamente.

É preciso um olhar treinado e sensível para observar a ocorrência desse português indígena. Nesse sentido, é necessário que o curso realize encontros para discutir e estudar o português indígena para, depois de eliminadas algumas 
dúvidas, aprofundar a proposta de promoção dessa variedade de português no FIEI. Ressalte-se que o curso tem pelo menos seis variedades de português indígena: Xakriabá, Pataxó, Pataxó Hã Hã Hãe, Tupinikim, Maxakali e Guarani.

Os trechos acima são também característicos de translinguagem. A translinguagem refere-se a práticas de linguagem que rompem com o pressuposto de línguas autônomas, fixas e tornam visíveis a complexidade de trocas linguísticas entre pessoas com diferentes histórias em contextos sociais, políticos e culturais específicos (GARCIA e WEI, 2014, p. 21). As práticas translíngues envolvem recursos semióticos diversos e não só a palavra (CANAGARAJAH, 2012, p. 6). Interessa observar como os falantes constroem significados a partir da mobilização de um repertório linguístico. Essa nova compreensão do uso das línguas em contextos multilíngues rompe com a noção de bilíngue ideal ou aditivo, a saber, o indivíduo que domina várias línguas, sem interferência de sua língua materna (LAMBERT, 1974). Garcia (2009, p. 45) explica que na translinguagem o falante seleciona estrategicamente certos elementos de seu repertório linguístico para uma comunicação efetiva, ou seja, para construir significados relevantes. Nos dois trechos abaixo, também retirado dos percursos acadêmicos dos autores, destacamse os usos de palavras das línguas indígenas no texto em português:

\section{TRECHO 4}

Para isto os ĩdxihi dizimaram nações inteiras em um verdadeiro processo de genocídio nacional. Segundo eles era para demarcar o novo território descoberto. Como uma pessoa pode achar que descobre algo se sabe que ali já tem dono? É como se alguém chegasse e entrasse em sua casa, encontrasse você lá dentro e falasse: eu descobri uma nova casa. [...] A partir de quando os colonizadores pisaram em nosso hãhãw e invadiram nosso território trouxeram consigo os seus maus costumes e suas ideologias destruidoras para serem implantadas em nossas terras, trouxeram o modelo capitalista, a igreja, a escola e impôs sua língua (BRAZ, p. 23; 47)

Pode ser dito que o uso dos vocábulos indígenas 'ĩdxihi' e 'hãhãw' é feito para marcar a diferença identitária entre o escritor indígena e o provável leitor não indígena. Há até sinônimos no trecho para 'ĩdxihi' (não indígena ou colononizadores) e 'hãhãw' (território), mas o uso dos vocábulos da língua ancestral parece ser uma estratégia mais potente na construção identitária Pataxó nesse momento. O mesmo pode ser observado no trecho 5:

\section{TRECHO 5}

Obrigado os professores

Exemplos a ser seguido

Peço que me desculpe

Se de alguém tiver esquecido.

[...] 


\begin{abstract}
Ariantãn Xakriabá e Guarani
Ariantãn Pankararu e Pataxó

Somos de etnias diferentes

Mas nossa luta é uma só

Busca conhecimento

Pra torna a vida na aldeia melhor.

(LOPES, 2016, sem numeração)
\end{abstract}

No caso acima, a alternância das palavras 'obrigado' e 'ariantãn' também está associada a construção identitária. Em 'obrigado' o uso refere-se ao não indígena - 'os professores', já o uso de 'ariantãn' é endereçado aos povos indígenas do curso FIEI - Xakriabá, Guarani, Pankararu, Pataxo. Tanto os trechos 4 e 5 como os anteriores exemplificam práticas translíngues nas quais os autores selecionam características do seu repertório linguístico com o intuito de construir significados. Reforçam também a necessidade de uma compreensão mais ampla dos usos das línguas pelos estudantes indígenas do FIEI e, portanto, a criação de metodologias de ensino que considerem os significados que esses falantes constroem em suas interações.

No que se refere aos projetos de reavivamento linguístico, há grandes lacunas. Isso porque, em primeiro lugar, é também nas disciplinas arroladas anteriormente que se busca instrumentar os estudantes para a realização desses projetos. O número reduzido de disciplinas aliado ao curto espaço de tempo, não permite o aprofundamento dessas questões de interesse dos povos indígenas. Ainda assim, alguns percursos acadêmicos vêm sendo orientados sobre essas questões e, desta forma, mais individualizada, pode se refletir um pouco mais sobre essas iniciativas. Os estudantes indígenas também vêm produzindo vídeos e materiais didáticos e discutindo metodologias de ensino das línguas em processo de revitalização, como o Patxôhã, do povo Pataxó, a língua Akwen Xakriabá, e a língua Pataxó Hã Hã Hãe. Alguns estudantes têm escrito o seu percurso acadêmico em português com algumas partes escritas nas línguas em processo de revitalização (vide, por exemplo, ABREU, 2016; BRAZ, 2016).

Em se tratando dos povos que falam o português como segunda língua, os estudantes indígenas têm níveis de compreensão variadas do português. São minoria considerando-se que as turmas são compostas basicamente de falantes de português como primeira língua. Além disso, também os professores falam apenas português. Apesar do esforço desses docentes em adequar as aulas e materiais didáticos aos diferentes estudantes, nem sempre isso é suficiente para atender aqueles que falam português como segunda língua. Uma estratégia tem sido o acompanhamento individual desses estudantes e aulas separadas por grupos linguísticos, com o 
intuito de que o português seja trabalhado como segunda língua, feito impossível nas turmas mistas.

O trabalho com as línguas Guarani e Maxakali também tem sido um desafio muito grande. O FIEI não conta com docentes falantes dessas línguas, o que limita enormemente a utilização desses idiomas na sala de aula. Além disso, não há materiais didáticos específicos em Guarani e em Maxakali, o que também prejudica a promoção dessas línguas. Ainda assim, a esses estudantes é facultado escrever seus trabalhos e percursos acadêmicos em versões bilíngues, nas suas línguas originárias com tradução para o português (vide, por exemplo, SOUZA, 2016). Esses esforços ainda não são suficientes para dar voz às línguas Guarani e Maxakali. Não raro esses estudantes permanecem em silêncio quase todo o tempo nas aulas, em face da pouca proficiência em língua portuguesa em comparação com os estudantes das outras etnias e, principalmente pelo fato de que os demais falantes não conhecem suas línguas.

É preciso ainda destacar uma ação que envolve o processo seletivo FIEI. Em 2011, houve uma solicitação ao colegiado FIEI, por parte dos povos ${ }^{10}$ Maxakali e Guarani, para que fossem inseridos no curso. O processo seletivo, que até então era realizado somente em língua portuguesa, sofreu modificações de modo a garantir a participação desses povos. Assim, os candidatos bilíngues Maxakali e Guarani puderam realizar a redação na sua língua de origem. Ainda que três candidatos Guarani tenham obtido êxito no processo, o mesmo não se deu com os Maxakali. Assim, no processo seletivo seguinte, em 2013, a comissão de elaboração da prova decidiu traduzir os enunciados para a língua Maxakali, após consultar os povos indígenas interessados a respeito de estratégias que poderiam facilitar a realização do teste. Também não houve êxito para os Maxakali, indicando que o instrumento não estava adequado à realidade desse povo. Em 2014, novas alterações no processo seletivo foram feitas: o número de questões foi reduzido, as instruções em Maxakali e Guarani permaneceram e os candidatos poderiam responder praticamente todas as questões em sua língua. Desta vez, seis candidatos Guarani e apenas um Maxakali conseguiram romper a barreira do instrumento do processo seletivo. Em 2015 e 2016 não houve candidatos Guarani, mas, foram realizadas novas mudanças no processo seletivo, garantindo sala específica para candidatos Maxakali, com a presença de um intérprete indígena Maxakali durante a prova. Entretanto, o instrumento continuou se mostrando inadequado ao povo em questão, o que gerou um amplo debate entre

10. Os povos indígenas sempre se referem no coletivo. Ao pedirem inserção no curso, pedem que o povo seja inserido e não indivíduos. 
professores e lideranças indígenas sobre as necessidades de uma reavaliação do processo seletivo do curso FIEI.

Em face das evidências de que o processo seletivo FIEI ainda não estava adequado ao povo Maxakali, o Conselho Consultivo Indígena do FIEI, juntamente com o colegiado FIEI, aprovou, em 2016, a realização de uma prova que fosse diferente daquela realizada pelos candidatos falantes de língua portuguesa como primeira língua. Desta forma, houve a construção de uma prova multimodal (com escrita, oralidade, vídeos e imagens), em língua Maxakali, com conteúdos mais próximos da realidade desse povo o que facultou a aprovação de 15 candidatos Maxakali. Essa experiência revelou que não basta traduzir os enunciados do Português para o Maxakali para que se obtenha a aprovação dos candidatos. Os conteúdos em Língua Portuguesa espelham a cosmovisão ocidental-capitalista, muito distante da realidade e do modo de vida desse povo, ainda que o FIEI sempre tenha balizado suas provas por temas que digam respeito aos povos indígenas ${ }^{11}$.

Por fim, mesmo que não direcionadas a todos os estudantes, merecem menção duas ações de extensão que buscam promover as línguas indígenas: 1 . o Programa Institucional de Bolsas de Iniciação à Docência - Diversidade (PIBID Diversidade) eixo Línguas, Artes e Literaturas (LAL), cujo objetivo (2014-2018) foi refletir sobre o ensino de línguas nas escolas das aldeias e, 2. Saberes Indígenas na Escola, que busca construir materiais em línguas indígenas. Os dois programas merecem ser ampliados e ter novos editais abertos uma vez que ainda há muito a se refletir sobre o ensino das línguas indígenas nos territórios e sobre a construção de materiais nessas línguas.

\section{ALGUMAS PROPOSTAS PARA A PROMOÇÃO DAS LÍNGUAS EM USO NO FIEI}

Com um cenário sociolinguístico muito complexo, o FIEI vem buscando reconhecer e promover as línguas indígenas faladas no curso. Há aspectos que precisam ser reforçados conforme observado acima. Primeiramente, é preciso reconhecer que o professor indígena, independente de sua habilitação, deverá estar apto a debater e propor políticas linguísticas em seus territórios. Dessa forma, o perfil do egresso poderia manifestar isso. Em segundo, as línguas faladas no curso precisam estar mais visíveis na proposta curricular. Uma possibilidade seria que houvesse disciplinas que nomeassem as línguas no curso tais como: Língua indígena:

11. As provas do processo seletivo FIEI estão disponíveis no site da COPEVE UFMG: https://www. ufmg. br/copeve/site novo/? pagina $=8$ 
português; Língua indígena: Maxakali i Língua indígena: Guarani, Língua indígena: Patxôhã ${ }^{12}$, dentre outras. Essas disciplinas poderiam ser parte de um núcleo comum a todas as habilitações, assim como outras que tematizem a reflexão sobre linguagem (Ensino de português como primeira e segunda línguas, Teoria linguística como instrumento para estudos de reavivamento linguístico, dentre outras), disciplinas essas que devem ir ao encontro das necessidades linguísticas dos estudantes e de suas comunidades.

Pode parecer contraditório, em face da discussão realizada sobre o conceito língua, que se proponha nomear as disciplinas, incorrendo em fixidez de uma língua. Entretanto, não se pode minimizar o poder de um currículo na visibilização das línguas faladas pelos povos indígenas. Conforme Silva (2010), currículo é relação de poder, é discurso, é território, é identidade. Nesse sentido, nomear as disciplinas fazendo referências às línguas indígenas é demarcar o território das línguas indígenas dentro desse documento de poder.

As metodologias a serem pensadas para o ensino dessas línguas, por sua vez, devem ser construídas considerando-se os aportes da translinguagem. Isso significa que as aulas não serão prescritivas ou focadas em gramáticas das línguas. Nessas aulas os repertórios linguísticos de estudantes deverão ser potencializados. Isso tem implicações na maneira como se compreende os textos orais e escritos desses estudantes bem como no planejamento e construção de aulas, avaliações e materiais didáticos.

Importante também seria que disciplinas como Maxakali, Guarani, Patxôhã, dentre outras, fossem ministradas por professores indígenas com fluência nessas línguas. Há professores com experiência e qualificação para isso. Seria uma tentativa de responder a uma agenda política indígena que busca mais representatividade na universidade, não só como estudantes, mas também como docentes. A um só tempo isso poderia contribuir para tornar o ensino mais efetivo assim como mais significativa a utilização e circulação dessas línguas nas salas de aula. Essa ação esbarra na burocracia da universidade que admite em seu quadro efetivo, apenas por concurso, prioritariamente professores que tenham doutorado. Mas, é uma maneira de pressionar o sistema para que ele se abra.

Outro aspecto a ser enfrentado é a falta de conhecimento que os docentes não indígenas, e por extensão o restante da equipe, têm das línguas de seus estudantes. Se existe um compromisso em promover essas línguas, os docentes talvez devessem aprender ao menos o básico dessas línguas. Se se considera que, em geral, todo

12. Obviamente esses nomes são apenas um exercício inconclusivo de pensamento. Quem debate e define são os atores indígenas e não indígenas do FIEI. 
docente universitário é fluente ou tem algum conhecimento em uma segunda língua que não o português, porque não investir em uma língua indígena? Essa qualificação docente deverá ser acompanhada também de ampliação do quadro docente do FIEI, em especial, os especialistas em Estudos da Linguagem, com o intuito de que os discentes tenham formação ampla oriundas de pontos de vista variados.

\section{CONSIDERAÇÕES FINAIS}

Este artigo discutiu alguns desafios que envolvem o trabalho com as línguas indígenas em cursos de licenciaturas interculturais. Há alguns passos a ser considerados na construção de políticas linguísticas que busquem promover e visibilizar as línguas indígenas na universidade. Em primeiro lugar, essas línguas devem ocupar alguns espaços simbólicos de poder, tais como currículos, devendo aí estar nomeadas e reconhecidas. Garantir audiências para as línguas indígenas, construir testes e materiais didáticos, além de facultar a escrita e a leitura nessas línguas são tarefas as quais o meio acadêmico, interpelado pela presença dos povos indígenas, não pode mais se furtar.

Em segundo lugar, urge que se problematizem conceitos teóricos cristalizados nos quais estão assentadas epistemologias e práticas de ensino e, principalmente, é improrrogável que se salte da problematização para ações efetivas. Sem o esforço do deslocamento teórico não há possibilidade de que novas teorias sejam engendradas, teorias estas que deveriam ser coconstruídas com os povos indígenas.

Por fim, a construção conjunta desse novo aparato teórico desafia a forjar um outro fazer, também inspirado nas maneiras próprias de ensinar e aprender indígenas. Aproxima-se dessa coconstrução de teorias e práticas a abordagem que sugere ser mais produtivo ao entendimento de textos orais e escritos, em contextos multilíngues, compreender o uso que o falante faz de seu repertório linguístico para construir significados.

\section{$\overline{\text { REFERÊNCIAS }}$}

ABREU, J. C. P.de. (2016). Cantos tradicionais do povo Xakriabá. 53 f. Trabalho de Conclusão de Curso (Licenciatura - Habilitação em Línguas, Artes e Literatura). Faculdade de Educação, Universidade Federal de Minas Gerais (UFMG).

BAKHTIN, M. (1997). Estética da criação verbal. Tradução de Maria Emsantina Galvão G. Pereira. $2^{\text {a }}$ ed. São Paulo: Martins Fontes. 
BAKHTIN, M. (1979). Marxismo e Filosofia da Linguagem. São Paulo, Hucitec.

BANIWA, G. A. (2013). Lei das Cotas e os Povos Indígenas: mais um desafio para a diversidade, Revista Fórum. Disponível em: https://www.revistaforum.com.br/ digital/119/ok-a-lei-das-cotas-e-os-povos-indígenas-mais-um-desafio-para-adiversidade/. Acesso em: 02 fev. 2018.

BRASIL. (2012). DCNEI - Diretrizes Curriculares Nacionais para a Educação Escolar Indígena. Disponível em: http://portal.mec.gov.br/index.php?option=com docman\&view $=$ download\&alias $=11074$-rceb005-12-pdf\&category_slug $=$ junho2012-pdf\&Itemid=30192. Acesso em: 09 out. 2017.

BRASIL. (2012). LEI N 12.711, DE 29 DE AGOSTO DE 2012. Disponível em: http:// www.planalto.gov.br/ccivil_03/_ato2011-2014/2012/Lei/L12711.htm. Acesso em: 01 mar. 2018.

BRASIL. (1997). Parâmetros curriculares nacionais: introdução aos parâmetros curriculares nacionais / Secretaria de Educação Fundamental. Brasília: MEC/SEF. Disponível em: http:// portal.mec.gov.br/seb/arquivos/pdf/livro01.pdf. Acesso em: 01 mar. 2018.

BRASIL. (1988). Constituição da República Federativa do Brasil. Disponível em: http://www. planalto.gov.br/ccivil_03/Constituicao/Constituiçao.htm. Acesso em: 10 out. 2017.

BRAZ, U. C. (2016). O ensino de língua patxôhã na Escola Indígena Pataxó Barra Velha: uma proposta de material didático específico. $73 \mathrm{f}$. Trabalho de Conclusão de Curso (Licenciatura Habilitação em Línguas, Artes e Literatura). Faculdade de Educação, Universidade Federal de Minas Gerais (UFMG).

CAJUEIRO, R. (2008). Os povos indígenas em instituições de ensino superior públicas federais e estaduais do Brasil: levantamento provisório de ações afirmativas e de licenciaturas interculturais. Trilhas de Conbecimento. Disponível em: http:// www.trilhasdeconhecimentos.etc.br/educacao superior indígena/arquivos/ Levantamento\%20de\%20A\%E7\%F5es\%20Afirmativas.pdf. Acesso em: 07 fev. 2018.

CALVET, L. J. (2002). Sociolinguística: uma introdução crítica. São Paulo: Parábola Editorial, 172 p.

CANAGARAJAH, S. (2012). Translingual Practice: Global Englishes and Cosmopolitan Relations. Taylor \& Francis Group. ProQuest Ebook Central: Disponivel em: http:// ebookcentral.proquest.com/lib/utxa/detail.action?docID $=1101434$. Acesso em: 22 dez. 2017. 
CAVALCANTI, M. C. (1999). Estudos sobre educação bilíngue e escolarização em contextos de minorias linguísticas no Brasil. D.E.L.T.A., vol. 15, nº especial, p. 385-417.

CAVALCANTI, M. C.; MAHER, T. J. M. (orgs.) (2018) Multilingual Brazil. Language Resources, Identities and Ideologies in a Globalized World. London: Routledge.

CÉSAR, A. L. S.; CAVALCANTI, M. C. (2007). Do singular para o multifacetado: o conceito de língua como caleidoscópio. In: Cavalcanti, M. C.; Bortoni-Ricardo, S. M. (orgs.) Transculturalidade, linguagem e educação, p. 45-66.

CHOMSKY, N. (1978). Aspectos da teoria da sintaxe. Tradução de José Antonio Meireles e Eduardo Paiva Reposo. 2. ed. Coimbra: Armênio Amado.

CHOMSKY, N. (1998) Linguagem e mente: pensamentos atuais sobre antigos problemas. Tradução de Lúcia Lobato. Brasília: Editora Universidade de Brasília.

D’ANGELIS, W. da R. (2005). Linguas indígenas precisam de escritores? Como formá-los? Campinas: CEFIEL - Centro de Formação Continuada do IEL-UNICAMP; Brasília: Ministério da Educação.

DOOLEY, R. A. (1998). Léxico Guaraní, Dialeto Mbyá: versão para fins acadêmicos Com acréscimos do dialeto nbandéva e outros subfalares do sul do Brasil. Disponivel em: http://www. museumaconicoparanaense.com/MMPRaiz/Biblioteca/1797 IDIOMAS\%20-\%20 Dicionario\%20Guarani.pdf Acesso em: 03 abr.2018.

FIEI - Formação Intercultural para Educadores Indígenas (2009). Projeto Político Pedagógico, Colegiado FIEI: Belo Horizonte.

GARCIA, O. (2009). Bilingual Education in the 21st Century: A Global Perspective UK: WileyBlackwell.

GARCIA, O.; WEI, L. (2014). Translanguaging: Language, Bilingualism and Education. New York: Palgrave Macmillan.

GORETE NETO, M. (2005). Construindo interpretações para entrelinhas: cosmologia e identidade étnica nos textos escritos em português, como segunda língua, por alunos indígenas Tapirapé, 129 f. Dissertação (Mestrado em Linguística Aplicada), Universidade Estadual de Campinas, Instituto de Estudos da Linguagem, Campinas, SP.

INSTITUTO DE INCLUSÃO NO ENSINO SUPERIOR E NA PESQUISA. (2012). Mapa de Ações Afirmativas. Brasília. Disponível em: http://www.inctinclusao.com.br/ acoes-afirmativas/mapa. Acesso em: 07 fev. 2018. 
HALL, S. (1992). A identidade cultural na pós-modernidade. Rio de Janeiro, DP\&A Editora.

IBGE - Instituto Brasileiro de Geografia e Estatística. Censo 2010. Estudos especiais. O Brasil Indígena. Língua Falada. Disponível em: https://indígenas.ibge.gov.br/estudosespeciais-3/o-brasil-indígena/língua-falada. Acesso em: 29 mar. 2018.

INSTITUTO NACIONAL DE PESQUISAS EDUCACIONAIS ANÍSIO TEIXEIRA. (2017) Sinopse Estatística da Educação Superior 2016. Brasília, INEP. Disponível em: http:// portal.inep.gov.br/web/guest/sinopses-estatisticas-da-educacao-superior. Acesso em: 06 fev. 2018.

LAMBERT, W.E. (1974). Culture and language as factors in learning and education. In: Aboud, F. E.; Meade, R. D. (eds.), Cultural factors in learning and education. Bellingham, WA: Fifth Washington Symposium on Learning, pp. 91-112.

LIMA, A. C. S.; BARROSO-HOFFMANN, M. (orgs.). (2007). Desafios para uma educação superior para os povos indígenas no Brasil: Políticas públicas de ação afirmativa e direitos culturais diferenciados. LACED: Rio de Janeiro. Disponível em: www.trilhasdeconhecimentos. etc.br/livros/arquivos/desafios.pdf. Acesso em: 30 jan. 2018.

LIMA e SILVA, M. (2011). Português Indígena Kaingang: Uma Questão de Concordância, $138 \mathrm{f}$. Dissertação (Mestrado em Linguística). Universidade Estadual de Campinas (UNICAMP).

LOPES, L. S. (2016). Loas e versos Xakriabá: tradição e oralidade. $64 \mathrm{f}$. Trabalho de Conclusão de Curso (Licenciatura - Habilitação em Línguas, Artes e Literatura). Faculdade de Educação, Universidade Federal de Minas Gerais (UFMG).

MAHER, T. J. M. A Educação do Entorno para a Interculturalidade e o Plurilinguismo. (2007). In: Kleiman, A. B.; Cavalcanti, M. C. (orgs.) Linguística Aplicada-suas Faces e Interfaces. Campinas, SP: Mercado de Letras, pp.255-270.

MAHER, T. J. M. (1996). Ser professor sendo índio: questões de lingua(gem) e identidade. 262 f. Tese (Doutorado em Linguística), Universidade Estadual de Campinas (UNICAMP).

MORELLO, R. (2012). A política de cooficialização de línguas no Brasil. Colóquio Internacional de Maputo: a diversidade linguística nos países de CPLP, v. 1, n. 1, p. 8-17 Disponível em: http:// www.youblisher.com/p/783318-Plato-Volume-1-N-1-Coloquio-de-Maputo-V1-2/. Acesso em: 09 out. 2017.

SAUSSURE, F. de. (1970). Curso de linguística geral. São Paulo: Editora Cultrix. 
SHOHAMY, E. (2014). Language Policy: Hidden Agendas and New Approaches. Taylor and Francis. ProQuest Ebook Central, Disponível em: http://ebookcentral.proquest.com/lib/ utxa/detail.action?docID=258983. Acesso em: 14 fev. 2018.

SILVA, T. T. da. (2010). Documentos de Identidade: Uma Introdução às Teorias de Currículo. $3^{\circ}$ ed. Editora Autêntica.

SILVA, T. T. da. (2000). A produção social da identidade e da diferença. In: Silva, T. T. (org.) Identidade e Diferença: a perspectiva dos estudos culturais. Petrópolis, RJ: Vozes, p. 73-102.

SOUZA, I. de. (2016). A cestaria Guarani Mbya da aldeia Sapukai - Bracuí (RJ). 38 f. Trabalho de Conclusão de Curso (Licenciatura - Habilitação em Línguas, Artes e Literatura). Faculdade de Educação, Universidade Federal de Minas Gerais (UFMG).

SPOLKY, B. (2004). Language Policy, United Kingdom: Cambridge University Press.

UFMG - Universidade Federal de Minas Gerais. (2017). Resolução Nº 02/2017, de 04 de abril de 2017 Disponível em: https://ufmg.br/storage/3/7/5/e/375ec9f3f14eea18e11 2ae5f2702030a_15045448481341_287882584.pdf. Acesso em: 01 mar. 2018.

UFMG - Universidade Federal de Minas Gerais. Resolução No 15/2016, de 30 de agosto de 2016. Disponível em: https://www2.ufmg.br/sods/Sods/Conselho-Universitario/ Documentos/Resolucoes-Comuns. Acesso em: 01 mar. 2018.

Recebido: 27/09/2018

Aceito: 9/10/2018 